\title{
Contemporary Theories of Cervical Carcinogenesis: The Virus, the Host, and the Stem Cell
}

\author{
Christopher P. Crum, M.D. \\ Division of Women's and Perinatal Pathology, Department of Pathology, Brigham and Women's Hospital \\ and Harvard Medical School, Boston, Massachusetts
}

Cervical cancer is a complex disease that, by its association with human papillomavirus (HPV), has elicited research in a broad range of areas pertaining to its basic diagnostic and clinical aspects. The complexity of this association lies not only in the fundamental relationship between virus and cancer but also in its translation to pathologic diagnosis and clinical management. Offshoots from the relationship of virus to pathology include studies targeting the link between papillomavirus infection and cervical epithelial abnormalities, the molecular epidemiology of papillomavirus infection, and the potential use of HPV testing as either a screening technique or a tool for managing women who have Pap smear abnormalities. A second variable that is critical to the pathogenesis of cervical neoplasia is the cervical transformation zone. The wide range of invasive and noninvasive lesion phenotypes associated with HPV infection in this region indicate that not only the virus but also specific host target epithelial cells in the transformation zone play an important part in the development of cervical neoplasia. Further understanding of this relationship between the virus and the host epithelium will hinge on determining the subtypes of epithelial cells in the transformation zone and their phenotypic response to infection. New technologies, such as expression arrays, promise to clarify, if not resolve, the complexity of molecular interactions leading to the multiplicity of tumor phenotypes associated with HPV infection of the uterine cervix.

KEY WORDS: Cervical neoplasm, CIN, Human papillomavirus.

Mod Pathol 2000;13(3):243-251

Copyright $(\odot 2000$ by The United States and Canadian Academy of Pathology, Inc.

VOL. 13, NO. 3, P. 243, 2000 Printed in the U.S.A.

Date of acceptance: November 8, 1999.

Address reprint requests to: Christopher P. Crum, M.D., Department of Pathology, Brigham and Women's Hospital, 75 Francis Street, Boston, MA 02115; e-mail: cpcrum@bics.bwh.harvard.edu; fax: 617-264-5125.
Throughout the past 20 years, the perception of cervical carcinoma has shifted from that of a mysterious, sexually transmitted disease to one intimately related to human papillomaviruses (HPVs). This evolution in understanding has been driven by a powerful association between virus and disease and by a wealth of molecular data supporting mechanisms of papillomavirus-mediated tumorigenesis (1). However, despite the extremely high rate of infection by these viruses, the rate of cervical cancer, even in the prescreening era, has been less than one tenth that of exposure. This underscores the potential importance of other factors in the pathogenesis of cervical carcinoma that come into play either before or after HPV infection.

This article addresses these issues from the perspective of their relationship to the tissue pathologic changes that both influence and result from cervical HPV infection. A series of concepts are addressed in this process, including their application (translation) to pathologic diagnosis or interpretation.

\section{HUMAN PAPILLOMAVIRUSES ALTER THE MORPHOLOGIC PHENOTYPES OF SOUAMOUS (AND GLANDULAR) CELLS}

HPVs are double-stranded DNA viruses approximately $8 \mathrm{~kb}$ in length (1). They are transmitted sexually, but the manner by which these viruses are transmitted is unclear, inasmuch as the male sexual partner may or may not harbor visible lesions (2). Nevertheless, sufficient virus is transmitted to produce infection, and the incubation period after sexual contact is in the order of a few months to more than 1 year, based on follow-up studies of HPV-positive women and incubation periods for tissues infected in vitro (3). When the virus is transmitted, it enters the epithelial cells via the basal layer and produces two general categories of epithelial change that are relevant to diagnostic classification. The first is viral cytopathic effect in the maturing, terminally differentiated cells, which includes koilocytotic atypia. This 
results from execution of the normal viral life cycle, which is encouraged by epithelial maturation (4). It is important to note that this process occurs in terminally differentiating cells that are incapable of dividing (Fig. 1). The second is an abnormality in the growth characteristics and differentiation of the epithelium that has its origins in a fundamental change in the replicating (basal/parabasal) cells. This phenomenon produces morphologic disturbances in all cell layers (Fig. 2) (5). The cellular alterations are mediated via HPV early (E6-E7) gene expression, leading to disruption of normal cell cycle processes and involving disruption of the functions of the $p 53, R b$, and other cell cycle genes. These latter events have been best documented in cancer-associated papillomaviruses (1).

Translation: Papillomavirus infections produce cytologic atypia as a function of these molecular alterations, associated with increased cellular DNA and proliferative activity. The latter extends to cells in the intermediate and superficial layers, presumably because of viral gene expression in these areas $(6,7)$. The degree and distribution of the cellular atypia, combined with the distribution of cells showing proliferative activity, usually will distin- guish HPV-infected epithelium from normal or reactive changes. Another parameter, cyclin E expression, may by its presence distinguish many HPVinfected epithelia from benign reactive changes in the cervix (8).

\section{CANCER-ASSOCIATED (HIGH-RISK) PAPILLOMAVIRUSES PRODUCE BIOLOGIC ALTERATIONS THAT ARE MORE LIKELY TO PROGRESS TO INVASIVE CARCINOMA}

High-risk HPVs, via the direct effects of viral oncogenes on the stem (immortal) or replicating cell population, initiate a progressive series of molecular events that disrupt normal cell cycle function, alterations that may increase susceptibility of the cell to DNA damage and progressive chromosomal derangements, including $3 \mathrm{p}$, and others $(1,9)$. These progressive alterations frequently are accompanied by integration of the virus into the host genome and genomic amplifications at 3q $(10,11)$. Viral integration guarantees perpetual expression of the viral oncogenes. These molecular changes are most consistently produced by the prototypic high-
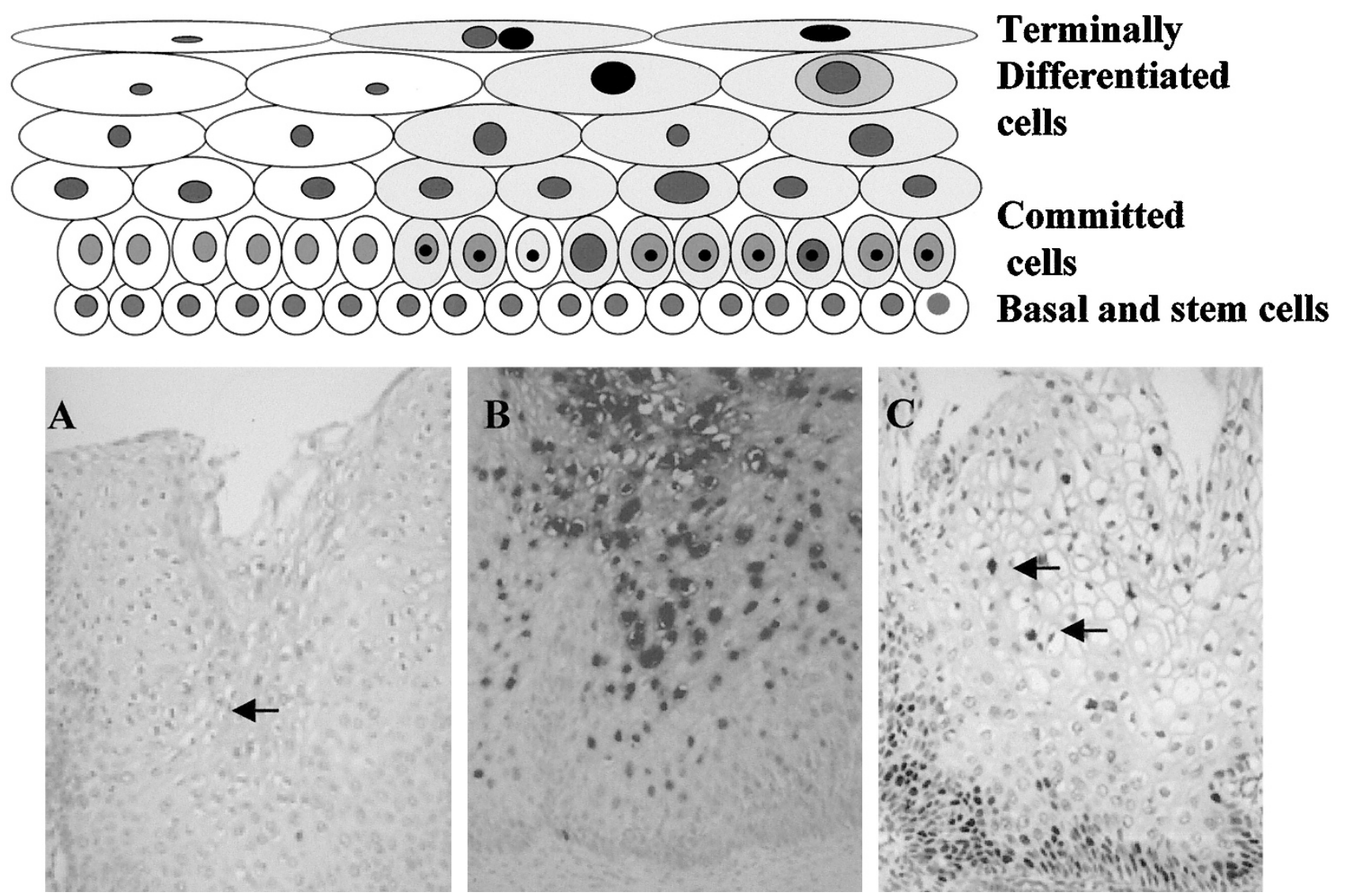

FIGURE 1. Top, the evolution of low-grade squamous intraepithelial lesions (right) from normal mucosa (left), which involves infection of basal cells and atypia confined principally to terminally differentiated cell nuclei. A, corresponding histology with koilocytosis (arrow). HPV DNA concentrates in these differentiated cells (B), stimulating cell cycle activity prompted by the virus, as determined by MIB-1 (Ki-67) immunostaining (C, arrows). 


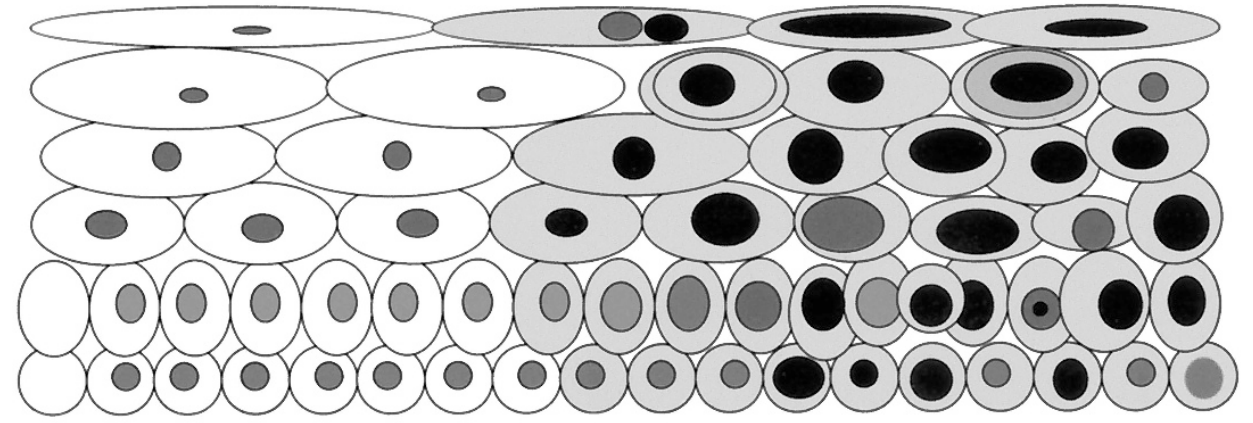

\section{Terminally Differentiated cells}

\section{Committed cells}

\section{Basal and stem cells}
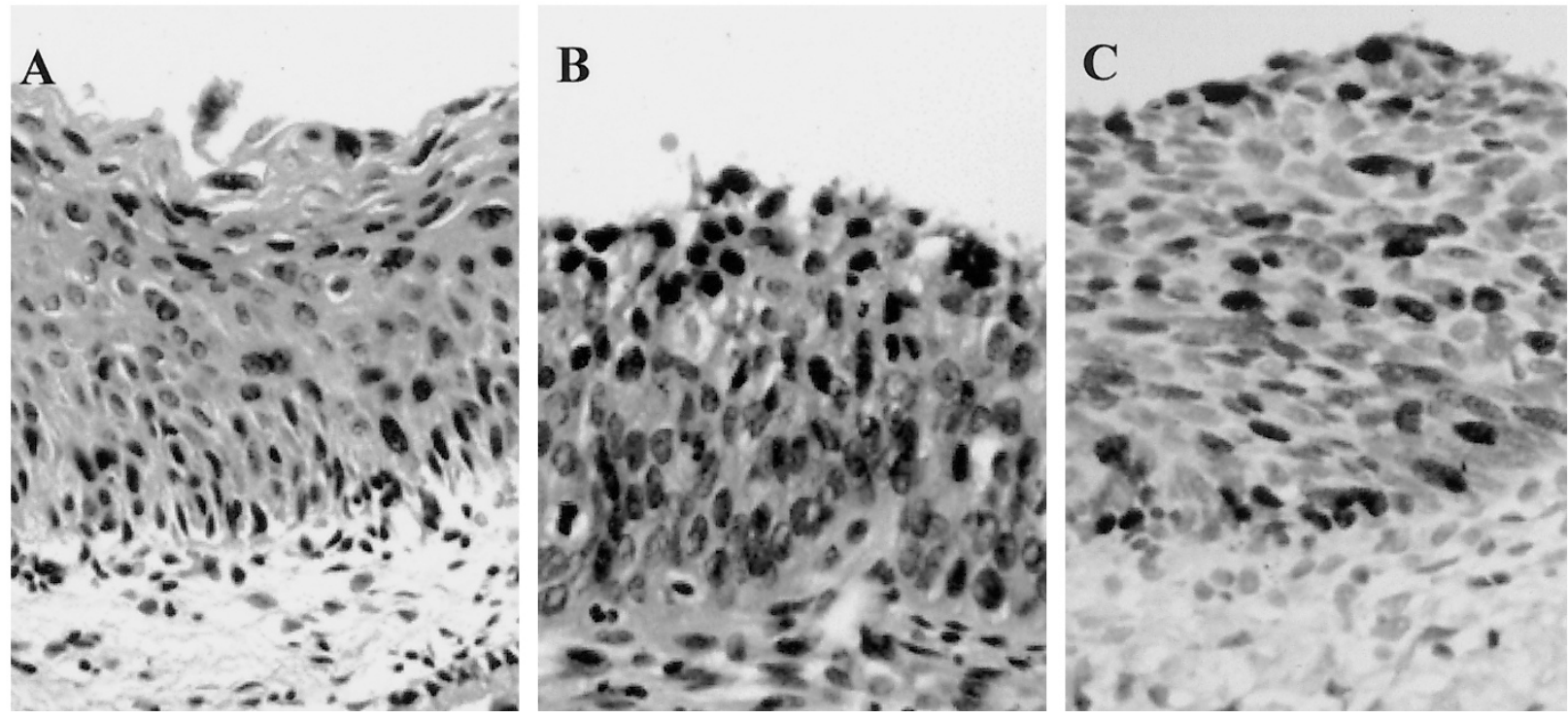

FIGURE 2. Top, the evolution of high-grade squamous intraepithelial lesions (right) from normal mucosa (left). This process involves not only infection of basal cells but also fundamental changes in the biology of these cells and their progeny, as reflected by full-thickness atypia in at least a part of the lesion. A and B, corresponding histologies of high-grade squamous intraepithelial lesions. C, a much higher index of cells undergoing proliferative activity than in low-grade squamous intraepithelial lesions, as determined by MIB-1 staining.

risk HPV type 16, but many others, including "intermediate risk" types (including types 18, 31, 33, $35,39,45,52,56$, etc.) may be associated with invasive cancer (12). The biologic events associated with high-risk HPV infection are diagrammed in Figure 3.

Translation: Approximately $90 \%$ of squamous precursor lesions that are produced by HPV type 16 exhibit the morphologic features of CIN II-III, and more than $50 \%$ of invasive squamous cell carcinomas contain HPV type 16 . Nearly $100 \%$ of invasive cancers contain HPV $(5,13)$.

\section{SOME "CANCER-ASSOCIATED" HPV TYPES HAVE A LOWER RISK FOR CANCER ASSOCIATION COMPARED WITH PRECURSOR DISEASE}

There is a wide range of associations between HPV and neoplasia. Certain HPV types, including those in the intermediate risk group, have a limited association with cancer. Others, such as type 18, which is highly oncogenic based on studies in vitro, may be observed in both low- and high-grade pre-

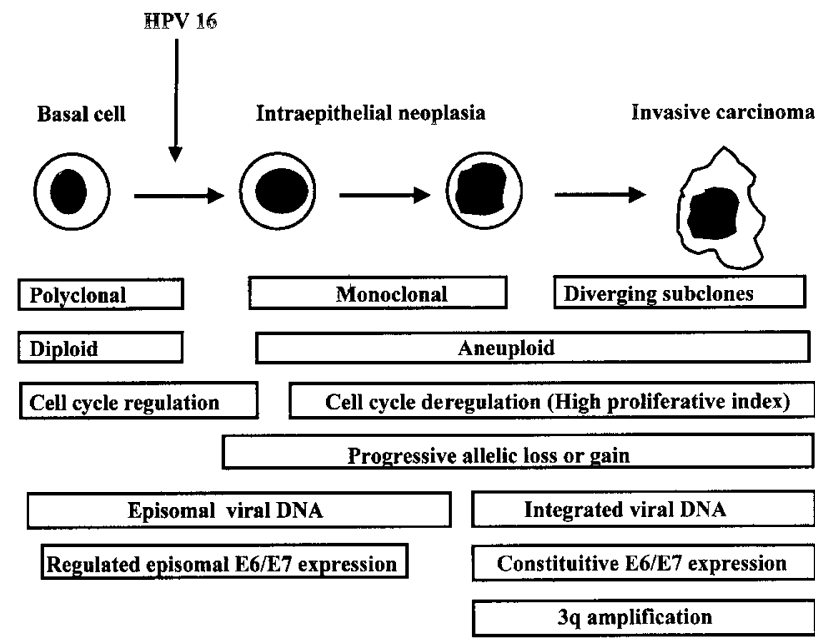

FIGURE 3. Viral and cellular events associated with infection by the prototypic high-risk human papillomavirus (type 16). Alterations that are fundamental to many invasive carcinomas include viral genomic integration, persistent expression of the E6/E7 oncoproteins, progressive allelic imbalance, and in many cases, amplification at 3q.

cursor lesions (14-17). Exactly why this occurs is not clear. One theory is that subtle variations in HPV sequence makeup produce variability in the 
biologic effects of a given virus type and thus the phenotype. This has been proposed for not only HPV 18 but also for others, such as type $16(18,19)$. However, there is a lack of corroborating studies that show that a particular sequence variant is more or less responsible for cancer or neoplasia. Central to this problem is that oncogenicity is often inferred from relative associations of a viral subtype with different lesions (19), and such conclusions must be verified by other investigators to exclude laboratory error or geographic bias. At present, the biologic significance of sequence variants within the same HPV type remains unclear, and it is assumed that host or environmental factors play an important role.

HPV types 31, 33, and 35 may be associated with precursor lesions at the lower end of the neoplastic spectrum (CIN I) (12). Some of these same types, including types 31,33 , and 35 , have been associated with "less aggressive" (relative to type 16) invasive carcinomas (see below). HPV 18 has been implicated in "more aggressive" tumors, including small cell undifferentiated carcinomas and adenocarcinomas $(14,20)$. In a recent study, significant differences in mortality were observed in women whose cancers were HPV 16/18 associated versus HPVs 31, 33, 35, and so forth (21). Such studies imply that although several HPV types are associated with carcinomas, the risks for progression through the precursor stage to invasion and the subsequent metastatic potential of tumors are, in part, virus dependent.

Translation: This has important implications for the interpretation of HPV DNA assays, particularly in the presence of low-grade cytologic abnormalities. Because a high percentage of low-grade squamous intraepithelial lesions (LSILs) are associated with intermediate- or high-risk HPV types, the value of HPV testing in the management of LSIL remains unresolved.

\section{THE CELLULAR ENVIRONMENT (TRANSFORMATION ZONE) INFLUENCES THE MORPHOLOGIC PHENOTYPE(S) ASSOCIATED WITH HPV INFECTION}

The cervix displays a dynamic of epithelial cell growth and differentiation, including the ingrowth of portio epithelium, the conversion of columnar epithelium to squamous epithelium via proliferation of reserve cells (squamous metaplasia), and endocervical cell proliferation and differentiation (22). Typically, the more cephalad (endocervical) areas display progressively less squamous differentiation (23). Although traditional teaching empha- sizes ingrowth or subcolumnar proliferation of squamous epithelial cells in the development of the transformation zone, a third mechanism, the existence of multipotential stem cells in the region of the squamocolumnar junction, may explain the emergence of multiple phenotypes-both benign and neoplastic-in this region.

There are no specific markers for stem cells in the cervix, but certain proteins are expressed preferentially in basal cells, which include stem cells. Certain keratins, beta integrins $(24,25)$, and CD8 (26) have strong predilections for immature squamous cells, including subcolumnar epithelium. Recently, a homologue of the $p 53$ tumor suppresser gene, named p63, has shown a strong association with basal squamous cells (27-29). The one and intriguing exception is in the transformation zone, where p63 highlights basal (stem?) cells underlying both columnar and squamous epithelium. P63 immunostaining, when combined with mucin stains, confirms the presence of both squamous and columnar differentiation pathways, often in the same locale (Fig. 4) (29). The impression from these observations is that basal cells that are contiguous with the exocervix are capable of these divergent pathways and, when infected by HPVs, may differentiate into multiple phenotypes. In this scenario, neoplastic cell differentiation would be dependent on the differentiation capabilities of the cells infected.

Translation: In practice, the morphology of cervical lesions is governed by not only HPV type but also the target cell, and these factors in turn have an important impact on classification and interpretation. For example, infections with the same HPV type may vary considerably in their appearance, often appearing less well differentiated (i.e., progress in grade) if they extend into or develop within the endocervical canal (30). HPV types 6 and 11 are associated with typical exophytic condylomata (LSIL) of the cervix. However, a subset of lesions produced by these HPV types display a sharp reduction in maturation and manifest as immature papillary lesions lined by a mildly atypical immature metaplastic epithelium. For such lesions, the terms papillary immature metaplasia (PIM), papilloma, and immature condyloma all describe an immature form of LSIL $(31,32)$ (Fig. 5A). The distinction between this lesion and conventional exophytic condyloma seems to be simply the type of epithelium infected. Similar lesions are produced in urethral or nasal (inverted papillomas) epithelium and are linked to similar HPVs (33). It is likely that the phenotype of high-risk HPV infection is also dependent on the differentiation and maturation characteristics of the infected epithelium. High-grade SILs (HSILs) with a metaplastic growth pattern have been described and are possibly 

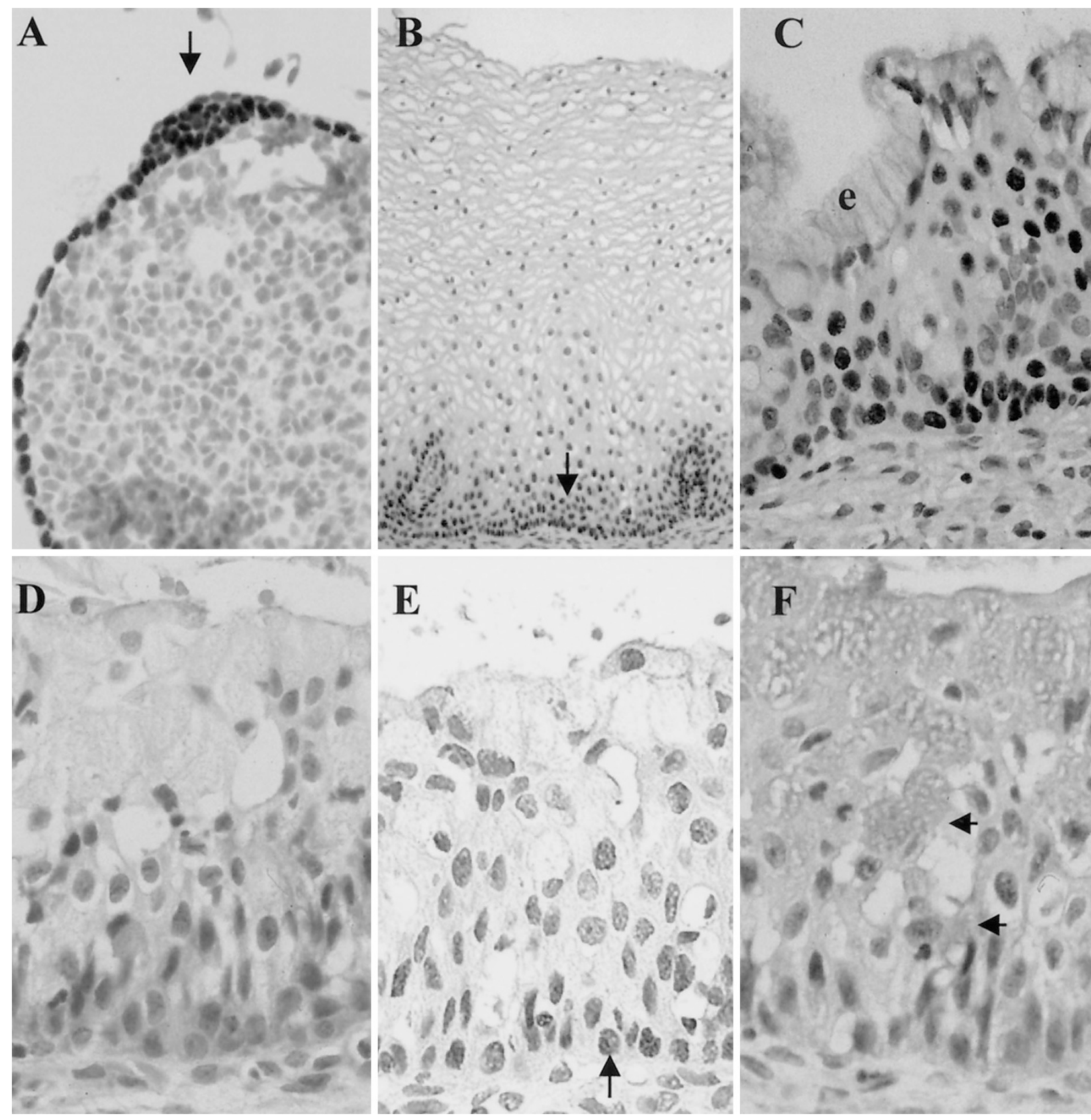

FIGURE 4. The cervical transformation zone, as depicted by immunostaining for p63, a protein closely linked to basal cell development and replenishment. In the mouse embryo (A), p63 is highly expressed in progenitors of squamous epithelium, including the apical ectodermal ridge (arrow). In the human cervix, p63 is concentrated in the basal and transient amplifying cells of the squamous epithelium (B, arrow) and in subcolumnar "reserve" cells (C). P63 also highlights basal stem cells capable of endocervical differentiation, shown in this stratified columnar epithelium (D), where the basal cells express p63 (E, arrow). P63 expression is downregulated with columnar cell (mucicarmine positive) differentiation (F, arrows). These findings suggest that p63 may identify basal cells giving rise to both squamous and endocervical columnar epithelium.

analogous to immature condylomas (Fig. 5B), arising in immature transformation zone epithelium $(34,35)$.

More intriguing are lesions that demonstrate both columnar and squamous differentiation. These may range from separate and distinct squamous (HSIL) and endocervical (adenocarcinoma in situ) components (Fig. 5C) to lesions that demonstrate a subtle transition from stem cell to squamous to endocervical differentiation (Figs. 5D, E) (36). Such lesions present the strongest argument that multipotential stem cells exist, the infection of which produces lesions with squamous and/or endocervical differentiation. Most compelling is the expression of squamous/basal cell markers in nuclei underlying poorly differentiated adenocarcinomas in situ, possibly identifying the multipotential neoplastic basal cells giving rise to these mixed lesions (Fig. 5F) $(29,36)$. The practical importance of this finding lies in the recognition of a multiplicity of patterns, some subtle, that are associated with HPV infection in the transformation zone. 

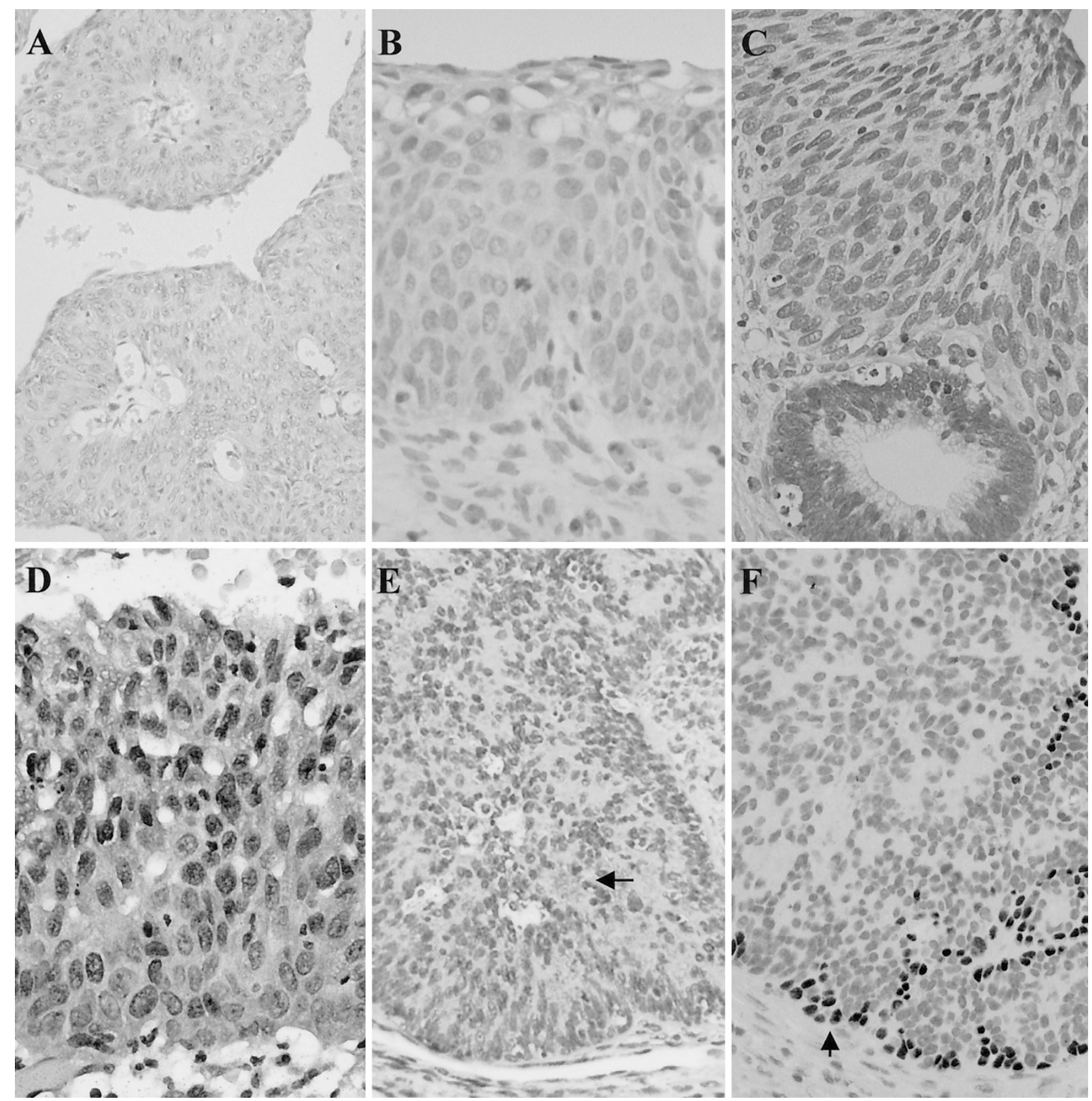

FIGURE 5. Phenotypic variants of early cervical neoplasia include immature low-grade squamous intraepithelial lesions (papillary immature metaplasia) associated with HPV 6 and 11 (A), high-grade squamous intraepithelial lesions (HSILs) with metaplastic growth patterns, including surface mucin droplets (B), coexisting HSIL (C, upper) and adenocarcinoma in situ (C, lower), and poorly differentiated variants combining features of both adenocarcinoma in situ and HSIL (D). The latter are distinguished from conventional HSIL by mucin stains (E, arrow) and a markedly reduced index of staining for p63. However, p63 immunopositivity may highlight basal cells in the latter (F, arrow), distinguishing these cells as neoplastic (multipotential?) basal cells. Compare with Figure 4D-F.

THE DETECTION OF PAPILLOMAVIRUSES PEAKS IN THE EARLY REPRODUCTIVE YEARS AS A FUNCTION OF SEXUAL ACTIVITY AND DECREASES MARKEDLY IN OLDER WOMEN, IN KEEPING WITH A SUCCESSFUL IMMUNE RESPONSE TO THE VIRUS

The morphologic evidence supports the concept that in healthy women, generated against the virus is an immune response that will protect against subsequent infections by the same type (37). This protective response will regulate the frequency that HPV exposure proceeds to a morphologic or cytologic abnormality. It will temper some infections, resulting in transient lesions in many women, and because the exposure to HPV is greatest in young sexually active women, older women will display a much lower index of HPV than younger individuals (38-40).

Translation: For practical purposes, immunologically intact women are not susceptible to HPV their entire lives. HPV detection in young women will 
exceed by several-fold the ability to detect abnormalities (39). Because postmenopausal women have a much lower index of HPV detection than they do cytologic abnormalities, the latter most often do not reflect significant cervical disease (41). As a rule of thumb, mild karyomegaly in intermediate or superficial cells in the Papanicolaou smears of menopausal and postmenopausal women carries minimal risk. Less mature atypias also frequently do not associate with HPV but invariably require follow-up (42).

\section{NUMBER AND TYPE OF HPV INFECTION MAY INFLUENCE PHENOTYPIC PRESENTATION, INCLUDING COEXISTENCE OF LOW- AND HIGH- GRADE PRECURSORS}

Multiple papillomavirus infections of the cervix are uncommon. In most cases, biologic progression of early cervical neoplasia takes place in the presence of a single infection $(43,44)$. However, in a proportion of cases, multiple infections may be present, leading to vastly different morphologies in a single cervix (43).

Translation: Although the evolution from CIN ICIN II to CIN III usually signifies the same HPV type-specific infection (44), coexistence of CIN I and CIN III can be attributed to either single or multiple infections. This must be considered when formulating opinions about "morphologic progression" in early cervical neoplasia (43).

Are some women more prone to multiple lesions? Are there certain combinations that are more common than others? We have observed several cases of HPV 6- and 11-positive papillary immature metaplasia associated with HPV 16-positive HSIL (32). Whether this association reflects shared risk factors as a result of exposure, a higher risk target epithelium, or both is not clear. Nevertheless, it underscores the importance of careful treatment of women with lesions of any grade or HPV type.

\section{HOST FACTORS WILL INFLUENCE THE PHENOTYPE OF HPV-RELATED DISEASES, FOR GOOD OR BAD}

As discussed above, certain factors, including age, exposures, and the evolving biology of the transformation zone, may influence risk for neoplasia after HPV infection. Adenocarcinoma of the cervix in young women has been associated with oral contraceptive use (45). Does this mean that hormonal factors influence the cell type selected by high-risk HPV infection? Adenoid basal carcinoma of the cervix, which is considered a "low risk" cancer, occurs almost exclusively in women in their 7th and 8th decades. Despite that this tumor is strongly associated with HPV 16, it progresses slowly (46, 47). Moreover, adenoid basal carcinoma displays a unique pattern of progression characterized by HSIL, an invasive squamoid component that gives way to an outgrowth of basaloid cells and endocervical (adenoid) differentiation. This progression generally is marked by a decreasing proliferative index and intense immunostaining for p63 in the basaloid cell populations (48). Is this unique pattern of progression the result of preexisting agerelated alterations in the target cells? A common link between adenoid basal carcinomas and aging (atrophic) epithelium is the similarity to basal or stem cells.

\section{ARE THERE OTHER GENETIC MARKERS OF VALUE IN ASSESSING CERVICAL CANCER RISK OR PROGRESSION?}

The following is a short list of potentially important markers or loci:

1. Proliferative markers: The index of cells expressing Ki-67 increases as a function of increasing lesion grade (7). The frequency and distribution of Ki-67 immunostaining may also distinguish non-neoplastic epithelium from either LSIL or HSIL.

2. P53 alterations: A recent study has suggested that the arg-arg homozygotes at AA 72 have a higher risk for cervical cancer (49). However, this has not been supported by molecular epidemiologic studies (50).

3. P63 (a p53 homologue) expression: This is an interesting gene expressed almost exclusively in endocervical reserve cells and immature squamous cells. It may prove to be useful in understanding the factors that influence differentiation of squamous neoplasia (27). In this author's experience, p63 is universally expressed in squamous carcinomas and sharply downregulated in adenocarcinomas and small cell undifferentiated carcinomas $(29,51)$.

4. $3 p$ deletions: Very common in both HPVpositive and -negative tumors and in an area with genetic instability. The specificity of this area for a tumor suppressor gene is unclear (9).

5. 3q amplifications: Quite specific for HPVpositive tumors. Many genes, including p63, are located in this area (11), but their relationship to neoplasia via this amplification is unknown.

6. Cyclin E expression: Much more common in cervical lesions versus non-neoplastic epithelium. However, sensitivity may hamper its use as a marker (8). 
7. MN antigen: A popular marker that is of uncertain value in distinguishing squamous neoplasia (13). It is highly expressed in glandular neoplasia, but its expression in some normal endocervical mucosae raises questions about specificity (52).

8. HPV testing: Numerous reports have supported, rebutted, and debated the use of HPV testing. Some authors have been critical of HPV testing, inasmuch as it has been proposed to alleviate newly introduced Papanicolaou smear diagnoses (atypical cells of undetermined significance) that cannot be reproducibly applied (53, 54). Nevertheless, the advent of highly sensitive assays $(53,54)$, and the potential value of HPV testing in treating women with abnormal glandular cells on Papanicolaou smear (55), or smear abnormalities after cone biopsy (56) support the further study of this test in the treatment of certain groups. Moreover, HPV-positive women are at significantly greater risk than HPV-negative women for developing cervical neoplasia, and this assay remains the most sensitive if not the most specific for HPV-associated disease (39, $57)$.

9. Other markers: The advent of RNA expression arrays and the potential to assess the expression of literally thousands of genes in neoplastic tissues and compare them with normal controls promises a new era of cancer diagnosis. It is conceivable that patterns of host gene expression that are unique to cervical neoplasia will be identified and that molecular assays that target one or more of these host genes will emerge with the goal of either replacing or augmenting HPV testing as an adjunct to the Papanicolaou smear. As such technologies evolve, they still must face the fundamental issues that surround cervical cancer prevention, which include sensitivity and specificity relative to the Papanicolaou smear and optimal delivery to women who are at risk. Moreover, the possibility exists that as the incidence of cervical cancer and cancer death rate diminishes, additional, albeit smaller, subsets of cervical cancer may emerge requiring different strategies of prevention.

Acknowledgments: The author is indebted to Frank McKeon and Annie Yang at Harvard Medical School for collaborative work cited in this article.

\section{REFERENCES}

1. Alani RM, Munger K. Human papillomaviruses and associated malignancies. J Clin Oncol 1998;16:330-7.
2. Barasso R. HPV-related genital lesions in men. IARC Sci Publ 1992;119:85-92.

3. Kreider JW, Howett MK, Wolfe SA, Bartlett GL, Zaino RJ, Sedlacek T, et al. Morphological transformation in vivo of human uterine cervix with papillomavirus from condylomata acuminata. Nature 1985;317:639-41.

4. Taichman LB, Reilly SS, LaPorta RF. The role of keratinocyte differentiation in the expression of epitheliotropic viruses. J Invest Dermatol 1983;81:137S-40S.

5. Crum CP, Mitao M, Levine RU, Silverstein S. Cervical papillomaviruses segregate within morphologically distinct precancerous lesions. J Virol 1985;54:675-81.

6. Demeter LM, Stoler MH, Broker TR, Chow LT. Induction of proliferating cell nuclear antigen in differentiated keratinocytes of human papillomavirus-infected lesions. Hum Pathol 1994;25:343-8.

7. Resnick M, Lester S, Tate JE, Sheets EE, Sparks C, Crum CP. Viral and histopathologic correlates of MN and MIB-1 expression in cervical intraepithelial neoplasia. Hum Pathol 1996;27:234-9.

8. Quade B, Park J, Crum CP, Sun, DQ, Dutta A. Cyclin E expression and early cervical neoplasia. Mod Pathol 1998;11: $1238-46$

9. Rader JS, Kamarasova T, Huettner PC, Li L, Li Y, Gerhard DS. Allelotyping of all chromosomal arms in invasive cervical cancer. Oncogene 1996;13:2737-41.

10. Cullen AP, Reid R, Campion M, Lorincz AT. Analysis of the physical state of different human papillomavirus DNAs in intraepithelial and invasive cervical neoplasms. J Virol 1991; 65:606-12.

11. Heselmeyer K, Schrock E, Manoir S, Blegen H, Shah K, Steinbeck R, et al. Gain of chromosome 3q defines the transition from severe dysplasia to invasive carcinoma of the uterine cervix. Proc Natl Acad Sci U S A 1996;93:479-84.

12. Lorincz AT, Reid R, Jenson AB, Greenberg MD, Lancaster W, Kurman RJ. Human papillomavirus infection of the cervix: relative risk associations of 15 common anogenital types. Obstet Gynecol 1992;79:328-37.

13. Resnick RM, Cornelissen MT, Wright DK, Eichinger GH, Fox HS, ter Schegget J, et al. Detection and typing of human papillomavirus in archival cervical cancer specimens by DNA amplification with consensus primers. J Natl Cancer Inst 1990;82:1477-84.

14. Smotkin D, Berek JS, Fu YS, Hacker NF, Major FJ, Wettstein FO. Human papillomavirus deoxyribonucleic acid in adenocarcinoma and adenosquamous carcinoma of the uterine cervix. Obstet Gynecol 1986;68:241-4.

15. Woodworth CD, Doniger J, DiPaolo JA. Immortalization of human foreskin keratinocytes by various human papillomavirus DNAs corresponds to their association with cervical carcinoma. J Virol 1989;63:159-64.

16. McLachlin CM, Tate J, Zitz J, Sheets EE, Crum CP. Human papillomavirus type 18 and low grade squamous intraepithelial lesions of the cervix. Am J Pathol 1994;144:141-7.

17. Kadish AS, Hagan RJ, Ritter DB, Goldberg GL, Romney SL, Kanetsky PA, et al. Biologic characteristics of specific human papillomavirus types predicted from morphology of cervical lesions. Hum Pathol 1992;23:1262-9.

18. Hecht JL, Kadish AS, Jiang G, Burk RD. Genetic characterization of the human papillomavirus (HPV) 18 E2 gene in clinical specimens suggests the presence of a subtype with decreased oncogenic potential. Int J Cancer 1995;60:369-76.

19. Zehbe I, Wilander E, Delius H, Tommasino M. Human papillomavirus 16 E6 variants are more prevalent in invasive cervical carcinoma than the prototype. Cancer Res 1998;58: 829-33.

20. Stoler MH, Mills SE, Gersell DJ, Walker AN. Small-cell neuroendocrine carcinoma of the cervix. A human papillomavirus type 18-associated cancer. Am J Surg Pathol 1991;15:28-32. 
21. Lombard I, Vincent-Salomon A, Validire P, Zafrani B, de la Rochefordiere A, Clough K, et al. Human papillomavirus genotype as a major determinant of the course of cervical cancer. J Clin Oncol 1998;16:2613-9.

22. Reagan JW, Patten SF Jr. Dysplasia: a basic reaction to injury in the uterine cervix. Ann N Y Acad Sci 1962;97:662-82.

23. Richart RM. Cervical intraepithelial neoplasia. In: Sommers SC, editor. Pathology annual. New York: Appleton; 1973. p. 301-28.

24. Smedts F, Ramaekers F, Robben H, Pruszczynski M, van Muijen G, Lane B, et al. Changing patterns of keratin expression during progression of cervical intraepithelial neoplasia. Am J Pathol 1990;136:657-68.

25. Watt FM. Epidermal stem cells: markers, patterning, and the control of stem cell fate. Philos Trans R Soc Lond B Biol Sci 1998;353:831-7.

26. Jih DM, Lyle S, Elenitsas R, Elder DE, Cotsarelis G. A cellular marker for the human hair follicle bulge identifies trichoepitheliomas and a subset of basal cell carcinomas. Mod Pathol 1999;12:58A.

27. Yang A, Kaghad M, Wang Y, Gillett E, Fleming MD, Dotsch V, et al. P63, a p53 homolog at 3q27-29, encodes multiple products with transactivating, death-inducing, and dominant-negative activities. Mol Cell 1998;2:305-16.

28. Yang A, Schweitzer R, Sun D, Kaghad M, Walker N, Bronson $\mathrm{R}$, et al. $\mathrm{P} 63$ is essential for maintaining proliferative capacity of ectoderm involved in limb, craniofacial, and epithelial development. Nature 1999;398:714-8.

29. Yang A, Yang YM, Sun D, Park JJ, Quade BJ, McKeon F, et al. P63: a p53 homologue that is a differentiation-specific marker in cervical squamous epithelium. Mod Pathol 1999; $12: 178 \mathrm{~A}$.

30. Koss LG, Stewart F, Foote FW, Jordan MJ, Bader GM, Day E. Some histological aspects of behavior of epidermoid carcinoma in situ and related lesions of the uterine cervix: a long-term prospective study. Cancer 1963;16:1160-211.

31. Ward BE, Saleh AM, Williams JV, Crum CP. Papillary immature metaplasia of the cervix: a distinct subset of exophytic cervical condyloma associated with HPV-6/11 nucleic acids. Mod Pathol 1992;5:391-5.

32. Trivijitsilp P, Mosher R, Sheets EE, Sun D, Crum CP. Papillary immature metaplasia (immature condyloma) of the cervix: a clinicopathologic analysis and comparison with papillary squamous carcinoma. Hum Pathol 1998;29:641-8.

33. Buchwald C, Franzmann MB, Jacobsen GK, Lindeberg H. Human papillomavirus (HPV) in sinonasal papillomas: a study of 78 cases using in situ hybridization and polymerase chain reaction. Laryngoscope 1995;105:66-71.

34. Geng L, Connolly DC, Isacson C, Ronnett BM, Cho KR. Atypical immature metaplasia (AIM) of the cervix: is it related to high-grade squamous intraepithelial lesion (HSIL)? Hum Pathol 1999;30:345-51.

35. Park JJ, Genest DR, Sun D, Crum CP. Atypical immature squamous proliferations of the cervix: reproducibility and viral (HPV) correlates. Hum Pathol 1999;30:1161-5.

36. Park JJ, Sun D, Crum CP. Squamo-mucinous intraepithelial (SMIL) and invasive lesions of the cervix: a distinct pathologic entity. Mod Pathol 1999;12:121A.

37. Nuovo GJ, Pedemonte BM. Human papillomavirus types and recurrent cervical warts. JAMA 1990;263:1223-6.

38. Rosenfeld WD, Rose E, Vermund SH, Schreiber K, Burk RD. Follow-up evaluation of cervicovaginal human papillomavirus infection in adolescents. J Pediatr 1992;121:307-311.

39. Moscicki AB, Shiboski S, Broering J, Powell K, Clayton L, Jay $\mathrm{N}$, et al. The natural history of human papillomavirus infection as measured by repeated DNA testing in adolescent and young women. J Pediatr 1998;132:277-84.

40. Melkert PW, Hopman E, van den Brule AJ, Risse EK, van
Diest PJ, Bleker OP, et al. Prevalence of HPV in cytomorphologically normal cervical smears, as determined by the polymerase chain reaction, is age-dependent. Int J Cancer 1993; 53:919-23.

41. Javonovic A-D, McLachlin CM, Shen L, Welch WR, Crum CP. Postmenopausal squamous atypia: a spectrum including "pseudo-koilocytosis" Mod Pathol 1995;8:408-12.

42. Crum CP, Cibas ES, Lee KR. Pathology of early cervical neoplasia. New York: Churchill Livingstone; 1997. p. 105-6, 122-3, 150.

43. Park J, Sun D, Genest DR, Trivijitsilp P, Suh I, Crum CP. Coexistence of low and high grade squamous intraepithelial lesions of the cervix: morphologic progression or multiple papillomaviruses? Gynecol Oncol 1998;70:386-91.

44. Wilbur DC, Bonfiglio TA, Stoler MH. Continuity of human papillomavirus (HPV) type between neoplastic precursors and invasive cervical carcinoma. An in situ hybridization study. Am J Surg Pathol 1988;12:182-6.

45. Thomas DB, Ray RM. Oral contraceptives and invasive adenocarcinomas and adenosquamous carcinomas of the uterine cervix: the World Health Organization Collaborative Study of Neoplasia and Steroid Contraceptives. Am J Epidemiol 1996;144:281-9.

46. Brainard JA, Hart WR. Adenoid basal epitheliomas of the uterine cervix: a reevaluation of distinctive cervical basaloid lesions currently classified as adenoid basal carcinoma and adenoid basal hyperplasia. Am J Surg Pathol 1998;22:965-75.

47. Grayson W, Taylor LF, Cooper K. Adenoid basal carcinoma of the uterine cervix: detection of integrated human papillomavirus in a rare tumor of putative "reserve cell" origin. Int J Gynecol Pathol 1997;16:307-12.

48. Cviko A, Briem B, Granter S, Pinto A, Yang A, Sheets E, et al. Adenoid basal carcinoma of the cervix: a unique model of morphologic progression favoring a "benign" multipotential stem cell phenotype case. Mod Pathol 2000;13:123A.

49. Storey A, Thomas M, Kalita A, Harwood C, Gardiol D, Mantovani F, et al. Role of a p53 polymorphism in the development of human papillomavirus-associated cancer. Nature 1998;393:229-34.

50. Sun D, Park J, Crum CP. P53 polymorphisms: do they really influence cervical cancer risk? Mod Pathol 1999;12:125A.

51. Wang T, Cviko A, Crum CP, Yang YC, McKeon F, Quade BJ. $\mathrm{P} 63$ as distinguishes squamous and non-squamous neoplasms of the cervix: an analysis of 350 cases. Mod Pathol 2000;13:134A.

52. Liao SY, Brewer C, Zavada J, Pastorek J, Pastorekova S, Manetta A, et al. Identification of the $\mathrm{MN}$ antigen as a diagnostic biomarker of cervical intraepithelial squamous and glandular neoplasia and cervical carcinomas. Am J Pathol 1994;145:598-609.

53. Kleter B, van Doorn LJ, ter Schegget J, Schrauwen L, van Krimpen K, Burger M, et al. Novel short-fragment PCR assay for highly sensitive broad-spectrum detection of anogenital human papillomaviruses. Am J Pathol 1998;153:1731-9.

54. Crum CP. Detecting every genital papillomavirus infection: what does it mean? Am J Pathol 1998;153:1667-71.

55. Ronnett BM, Manos M, Ransley JE, Fetterman J, Kinney WK, Hurley LB, et al. Atypical glandular cells of undetermined significance (AGUS): cytopathologic features, histopathologic results, and human papillomavirus DNA detection. Hum Pathol 1999;30:816-25.

56. Chua KL, Hjerpe A. Human papillomavirus analysis as a prognostic marker following conization of the cervix uteri. Gynecol Oncol 1997;66:108-13.

57. Liaw KL, Glass AG, Manos MM, Greer CE, Scott DR, Sherman $\mathrm{M}$, et al. Detection of human papillomavirus DNA in cytologically normal women and subsequent cervical squamous intraepithelial lesions. J Natl Cancer Inst 1999;91:954-60. 